\title{
BOSNIAN IDENTITY BETWEEN NATIONALISM, (IN)TOLERANCE AND (A)THEISM
}

\author{
UDC 316.74:2(497.6) + 323.1(497.6)
}

\begin{abstract}
Alma Jeftić
Faculty of Arts and Social Sciences, International University of Sarajevo, Bosnia and Herzegovina
\end{abstract}

\begin{abstract}
This article discusses the historical changes in religious practices in BosniaHerzegovina from the communist era to the post-war period in line with their influence on identity and intergroup (inter-ethnic, inter-religious) relations. There is a lack of evidence on whether people did not overtly express their religious beliefs during communism even though they were covertly religious, or whether they started engaging in the religious practice during and after the 1992-1995 war in order to establish group connectedness, cohesion, and fulfill certain needs. "Bosnian identity" will be described as a puzzle formed by the "remains" of the previous regime and the "new additions" of the post-war period. The discourse of power dominates in Bosnia-Herzegovina and enables prohibitions of different types of dialogue that can lead to better understanding of differences and Other(s). The main problem that will be addressed in this article is the (non)existing Bosnian identity analyzed through "jouissance" of nationalism, intolerance and religion. The contradictions of Sigmund Freud's concept of identification, and the relation of that concept to the body and power in a post-war divided society will be discussed. We can conclude that the main discourse of power operates with religion in order to establish the "jigsaw puzzle of Bosnian identity". The presence of those who either live in a different system (yugonostalgic people, Homo Yugoslavicus), or those who do not believe (atheists) simply adds a new dimension to the currently established system which can be used to further explain if the overtly expressed beliefs will remain unchanged in case of the establishment of a new system.
\end{abstract}

Key words: identity, intolerance, religion, Communism, Homo Yugoslavicus, BosniaHerzegovina

Received July 3, 2016 / Accepted July 21, 2016

Corresponding author: Alma Jeftić

International University of Sarajevo, Faculty of Arts and Social Sciences, Hrasnička cesta 15, 71210 Sarajevo, Bosnia and Herzegovina

E-mail: alma.jeftic@gmail.com 


\section{INTRODUCTION}

This article discusses the historical changes in religious practices in BosniaHerzegovina from the communist era to the post-war period in line with their influence on identity and intergroup (inter-ethnic, inter-religious) relations. There is a lack of evidence on whether people did not overtly express their religious beliefs during communism even though they were covertly religious, or whether they started engaging in religious practice during and after the 1992-1995 war in order to establish group connectedness, cohesion, and fulfill certain needs. Regardless of which approach one supports, it is evident that the higher level of religiosity among Bosnians did not contribute to greater social cohesion, tolerance and suppression of nationalist rhetoric at the present time. In this paper the term "Bosnian identity" is understood as a combination of several "remains" from the past regime (Communist and post-Communist era), and "new-additions of the 1992-1995 war and post-war period. Following these claims, the analysis includes Homo Yugoslavicus as a representative of the past regime, New Man who lives in contemporary society and who has embraced its principles, and New-Old Man who lives in contemporary society but who did not embrace all the principles fully.

The theoretical perspectives of Michel Foucault and Jacques Lacan will be used to explain the onset of intolerance and nationalism in multicultural societies like BosniaHerzegovina. Although these social and psychological theorists have not written extensively on this issue, their work contributes a lot to the contemporary analysis of post-war divided societies. Their ideas are important particularly for the insights they provide into the links between religion and power.

The main problems that will be addressed in this article are: the ways through which Bosnians have (not) been engaging in religious practices from the communist regime until the present time, the position of Homo Yugoslavicus, New Man and New-Old Man in contemporary society, and the jigsaw puzzle of Bosnian identity that can be defined as a byproduct of surplus of religion, group divisions and intolerance created in order to correspond to the current socio-political milieu.

The contradictions of Sigmund Freud's concept of identification, and the relation of that concept to the body and power in the post-war divided society will be discussed in order to determine whether the main discourse of power operates with the aim to establish three main constituent groups of people that will continue to (ab)use religion in order to fulfill their extrinsic needs and promote (in)tolerance.

\section{SLAVIC NARRATIVE ON RELIGION AND IDENTITY}

Julia Kristeva (1982) emphasized that psychoanalytic discourse on the Balkans constructs the region according to certain theoretical tenets and then attempts to disidentify with its own construction as if it were an "essential" Balkan identity. In order to define a symbolic space and civic subjectivity Kristeva (1982) abjects the Balkans as the filth of Europe and invokes her "theory of the abject", psychoanalytic theories of character, civilization, and sexuality, as well as the logic of exclusion. On the grounds of the abovementioned arguments, Kristeva asks the rhetorical question: "When did God die in the Balkans?"

According to Kristeva Christianity is deeply rooted in European cultural memory and it also represents a symbolic structure of complete subjectivity, therefore, historically, 
Western and Orthodox Christianity represent different cultural memories and explain Europe's cultural aporia because they constitute different and incomplete subjectivities (Kristeva 2000). That contributes to the fragmentation of the identity and prevents Balkan countries from developing one unique civic narrative.

Kristeva $(1982,2000)$ attributes to Orthodox Christianity a large share of the blame for the rise of "tribal" nationalism in Eastern Europe and the Balkans, and she also constructs an analysis of the "Orthodox psyche", which should be understood as a power discourse on the "Orthodox body". However, her theory is built upon Freud's theory of the Oedipus complex; therefore, she described Western Christianity as rational and Orthodox Christianity as emotional. Kristeva $(1982,209)$ offers this psychoanalytic interpretation of the Roman Catholic and Orthodox interpretations of the Holy Trinity: "If one is attacked as filth, one must fight back as filth!"; therefore, she suggests the means for turning the tables on her representation of the Balkans as abject of Europe's superego: "For, facing abjection, meaning has only a scored, rejected, ab-jected meaning - a comical one" (Kristeva 1982, 209). In this sense, she associated abject and abjection to Freud's analysis of jokes and humor, especially his jokes on Jews.

Sigmund Freud was a well-known for his willingness to use humor to illustrate a psychoanalytic concept and to express his own emotions about aspects of his struggles as a Jew and as the originator of psychoanalysis. His theory on sublimation and anal eroticism had played a part in the discursive development of the Balkan identity as he maintains that the Balkan people have a proclivity for anal eroticism that impedes sublimation and the civilizational process (Freud 1968, 10:214).

Bjelic (2006) analyzed the etymology of the word "Slav" and discovered that it was derived from the word "slovenly" which means "lazy and dirty" according to the Oxford English Dictionary. It is an important etymological detail because it may strengthen Freud's allusion to the Balkans' homoerotic desires between two sleeping men and also Kristeva's about the latent homosexuality of Orthodox Slavs, since it seems that the Oxford English Dictionary has conspired in the creation of a linguistic hegemony, which has contributed to the self-essentialization of Balkan anal identity (Bjelić 2006). However, linguistic hegemony implies more than two explanations of the Balkan identity, especially when it refers to the Bosnian identity, since it includes all the important aspects of the puzzle: communist identity, post-communist identity, and postwar identity (1992-1995 war).

It is interesting how the puzzle has changed through time in a way that the communist secular picture was replaced by a religious picture of three influential religions that compete among each other in a number of pieces that they embrace in one puzzle. However, it is also important to mention that these changes have not occurred over night, and that the distance from "Homo Yugoslavicus" has led to the creation of three (or even more, if we count non-constituent people) groups of individuals. While Homo Yugoslavicus was living according to the rules that, in Žižek's sense, used to combine pleasure with certain constraint, New Man has exposed his/her body in the real Foucault's sense: a place where even the most subtle social skills form a network of relationships that enable a wide scale of power to be organized.

That switch from the democracy of "chocolate laxative" to the "free New Man" has brought completely new constraints in terms of everyday activities, work, social gatherings and the expression of religion. As much as Homo Yugoslavicus was constrained in terms of his/her freedom to express and practice religion, free New Man 
and New-Old Man are forced to freely and openly expresses his/her religious and spiritual self. One of the major threats in contemporary Bosnia-Herzegovina can be symbolically presented in the shape of the old Homo Yugoslavicus (and New-Old Man if he/she is still embracing the remains of the old regime) who represents the return of the politics of previous times. However, the idea that all those who share the ideal of the exYugoslav "brotherhood and unity" can outnumber the New Men emerges as another disappearance of God in the Balkans (or, more precisely, Bosnia-Herzegovina). The question here is not the simple appearance or disappearance of religion in Bosnia, or the way through which members of the puzzle engage in religious practice, but the reasons for the uses and abuses of religion for the sake of tolerance and freedom. Having in mind the complicated historical background of Bosnia, a brief analysis of representation of religion in this region will be provided.

\section{OVERT AND COVERT RELIGIOUS PRACTICES IN BOSNIA-HERZEGOVINA THROUGH HISTORY}

Bosnia-Herzegovina as a country represents the meeting place of different peoples, customs and religions. It is inhabited by three major ethnic and religious groups: the Roman Catholic Croats, the Muslim Bosniaks, and the Eastern Orthodox Serbs. However, during its history Bosnia experienced several changes related to the visibility of religious practices, customs and symbols due to the different political regimes. It is interesting to notice that during communism religion was neither publicly expressed nor practiced, while the country underwent a period of increased religiosity after the fall of communism in the 1990s, which was also accompanied by the 1992-1995 war. During the war the engaged parties defined themselves mostly in terms of their religious identities.

However, there have been no strong indicators that could explain it if people have become more openly religious since the signing of the Dayton agreement, or this increase in religiosity is mostly a result of the conflict or the fall of Communism (Hacić Vlahović 2008). It is difficult to conclude with certainty how and why the religious revival occurred at the beginning of the 1990s in Bosnia-Herzegovina, and to which extent the complicated jigsaw puzzle has started to shape both the political and everyday life of ordinary Bosnian. It is also unclear whether people have become more openly religious due to nationalist sentiments, opportunism, the economic standard or intrinsic belief. The data collected during the communist period leave some degree of reasonable doubt as to whether society had actually truly secularized in the first place, or if people had simply pretended to become less religious in order to protect themselves (Hacić Vlahović 2008).

In order to understand both religious practices and the ways through which religion has been spreading in Bosnia-Herzegovina (and the Balkans in general), one has to take into consideration the beliefs, self-identification, emotional responses to religion as well as intergroup processes between different religious groups through history. Also, it should not be forgotten that the growth of religiosity during and after the 1992-1995 war may be a case of the increase in the public visibility of religiosity which does not necessarily need to be related to the changes in beliefs and practices.

Since religious identity and ethnic identity in Yugoslavia were closely interwoven, religion was seen as an obstacle in the effort to unite the country and was therefore limited (Bringa 2002). According to Bringa (2002) this was done in order to preserve social cohesion and prevent nationalism. Therefore, religion was becoming a marginal 
aspect of the citizen's belief and a phenomenon which appeared to survive mainly in rural areas and among the less educationally advanced and older segments of the population (Cohen 1998, 47). The real progress in secularization happened in the 1960s due to a demographic change, and the number of believers decreased by thirty percent between 1964 and 1968, while the number of those claiming to be atheist or non-religious increased by more than twenty percent (Hacić Vlahović 2008).

A study conducted by the Institute for the Study of National Relations in 1988 showed that respondents not only continued to rely on religion, but that religion was once again emerging as an important factor in political life (Velikonja 2003). The census data from the 1970s and 1980s show that religious practice among Yugoslav youth was steadily increasing, from a low rate of $11 \%$ in 1974 to $34 \%$ in 1989 (Hacić Vlahović 2008). It is also important to mention that a large percentage of the population identified with their national religion, even when they did not practice that particular religion. When asked directly in 1988, between $57 \%$ and $60 \%$ of people in all three ethnic groups believed that religion could be used as a surrogate for national identity (Velikonja 2003).

Even though religion was marginalized during the communist era, it was still present in society and among its members; also, it started to play a role in ethnic and national identification in Bosnia-Herzegovina. In the 1990s communism was failing throughout Europe, while in Bosnia democracy brought religious freedom and the visible expression of religious symbols and practices (Bringa 2002). However, religion started being exploited by nationalist leaders who were using it as a means to form cohesive groups. From a profoundly secularized society, in which religion and religious institutions had been even more marginalized than in other parts of Eastern Europe, over the course of only two decades the countries in the Western Balkans have become societies with high rates of religious identification, while religious communities have acquired a prominent place in public life (Đorđević 2007, 79-93, according to Van Den Berg et al. 2014).

It is difficult to say how much religious beliefs in Bosnia have to do with devoutness and intrinsic values, on the one hand, and personal interests and extrinsic values, on the other. Forty years of communist rule dramatically reduced all religious elements and overwhelmed the jigsaw puzzle formed of small parts of complex identities. However, after the dissolution of Yugoslavia the people's desire to express their belonging to an ethnic or national community resulted in the public expression of religious beliefs. These, of course, threaten the secular character of the state and displace some inhabitants outside of the state borders and erase them from the puzzle. Atheists exist only as a threat for the newly established community, and, in order to survive, they have to express an indefinite level of tolerance towards their religious friends, very often ex comrades. The most interesting point about the jigsaw puzzle of Bosnian identity is the fact that small pieces consist of both religious and secular pictures which can be replaced in different ways and orders, making the puzzle very changeable based on the political situation, level of tolerance, personal desire and estimation of the current situation.

However, the position of atheists in contemporary Bosnia-Herzegovina cannot easily be described in terms of a "group without a religion". Some of these people were born in religious families but decided not to have any ties with religion; some of them were born and raised in atheist families; and some of them decided to become atheists in the later stages of their lives. Not being visibly engaged in religious practices means not to exist in terms of participation in other social and political spheres. While Homo Yugoslavicus was a part of the political structures mainly because he/she was not practicing religion (at 
least not visibly), today's man has to adapt his/her body to the visible religious rituals in order to be perceived as a part of the social group. More or less similar explanations are coming from the former Soviet Union.

Dramatic religious growth has occurred throughout the former Soviet Union in the past 30 years with approximately 100 million people joining religious groups for the first time (Froese 2004a). These religious revivals correspond to lessening restrictions on religious activity, and a comparative analysis of post-communist countries reveals that levels of religious pluralism are not commensurate to the levels of religious growth (Froese 2004a). Froese (2004b) provides the following explanations for the revival of religion in Russia: the diminishing of restriction on religious activity after the fall of the Soviet Union, and the prior conversion of the Russian people to scientific atheism which proved to be quite unsuccessful.

If one attempts to compare former Soviet Union and former Yugoslavia in terms of religious revival after the dissolution of the countries he/she will most probably be caught in the religious-economies explanation of post-communist religious growth. When Robert Orsi talks about the study of lived religion he claims that it is shaped by and shapes the way family life is organized in terms of how the dead are buried, children disciplined, the past and present imagined, moral boundaries established and challenged, homes constructed, maintained and destroyed, the gods and spirits worshiped and importuned and so on (Orsi 2002, xxxii). Lived religion can also be viewed as a tool that provides new insight into the body, power, private and public space, and nationalism. Having in mind all of the above, one can conclude that the reasons for religious revival and the engagement into religious practice in Bosnia do not rely on intrinsic motivation and spiritual growth. However, there is no clear or empirically based link between new practitioners of religion and their extrinsic motivators besides the fact that only those who belong to one of the three main religious groups can enjoy benefits in terms of advancement in their career, scholarships, political positions and functions in government (including candidacy for the member of the Presidency). Those whose identity does not resemble one of the "big three" belong to the group of "Others" and thus lose the opportunity to get a position in the government or to become member of the Presidency.

These "Others" include atheists, Jews, the Roman population, people from the "mixed religious" marriages who refuse to declare their religion and/or are mainly atheists. Some of them still share the spirit of Homo Yugoslavicus and believe that the idea of brotherhood and unity was the best solution for the people in the ex-Yugoslav region. Therefore, there is a battle between the surplus of religion on one side and the loss (or at least, lack) of religion on the other side. Regardless of being "visibly" religious in more or less the same way, the majority is still divided into three smaller groups of Muslims, Catholics and Orthodox. The battle of "who is the majority" and "who will outnumber" has been existing since the establishment of those groups and has been mainly related to the religioussupply chain of extrinsic motivators.

According to the World Values Survey data, in 1998 69,8\% of Bosnians said that they were religious but by 2001 , this figure had increased to $74,3 \%$, which seems to indicate a significant increase in religiosity when compared to the latest pre-war data collected in 1990, when only $43 \%$ of the population of the former Yugoslavia self-identified as religious (Hacić Vlahović 2008). According to Hacić Vlahović $(2008$, 80), the apparent growth in religiosity that happened in the 1990s is probably the result of the complex interaction of different factors such as: the recent war in which different national groups 
were involved, unresolved problems with resettling war refugees, the active political role that religious leaders played during and after the war, a difficult post-communism transition from a centrally controlled to a market economy and the resulting erosion of social benefits, and, the introduction of religious education in schools. Also, major ethnic cleansing and resettlement led to significant socio-demographic changes resulting in the migration of the rural population from villages to the city centers.

In the interviews Ana Hacić-Vlahović conducted with religious leaders and scholars in Bosnia-Herzegovina during 2008, many of them were uncertain whether true religiosity has come to the forefront but they argued that many people stated that they were religious, regardless of whether they were actually believers because it was advantageous to be religious. One of the things they all agreed on was that religion has become more visible today than it was before, but without providing a special explanation of why that happened. Also, some religious leaders warned that in this context, religion was used to create barriers between people. Today, more than twenty years after ending the war in Bosnia and Herzegovina the actual question is how religious attitudes are influencing the readiness for reconciliation between three big religious groups.

In his study on religious attitudes and readiness for reconciliation, Puhalo (2015) discovered that the least readiness for cooperation can be found among confident believers, while forgiveness is highest among uncertain, agnostics and atheists. Also, Petrović (2010) found that the "older" generation (people who lived in former Yugoslavia) were more ready for reconciliation than "younger" generations who were born during the 1992-1995 war or later. It is still unclear whether the revival of religion after the fall of communism led to the strengthening of national identities which further led to the revival of animosities and even hatred among three religious groups (and the fourth one - "Other", to which atheists belong). However, it is evident that the way the majority has been expressing their religious attitudes and the ways through which the majority has been practicing religion and expressing religious symbols have led to the revival of nationalism and intolerance.

\section{LIVED RELIGION AND DEAD TOLERANCE IN BOSNIA-HERZEGOVINA}

Religion serves as a constituent element of nationalism and in the Western Balkans, for example, religious communities were the main catalyst of nationalism and division. According to Rogobete (2009), religion can be rehabilitated by the ethnic conflicts that can later on cause more violence and aggression. The current situation in the ex-Yugoslav countries proves that argument, while divided communities exist on the basis of their religious and ethnic identities which serve as shelter and approval for in-group wrongdoings.

Durkheim (1912/2008) argued that God is a symbolization of the social; therefore, religious nationalism appears as the public return of religion. Derrida writes that religion "is prescribed, not chosen freely in an act of pure and abstractly autonomous will" (Derrida 1998, 27). Derrida makes it immanent in the social bond itself, in the miraculous qualities of the relationship between every self and every other, in the logic of the response, the action elemental to all social relations that religion is not in religious institutions, but in the institution itself, in the unengendered, unnamable, unproducible conditions that precede and are immanent in social being. Described that way, religion is not centered, but spread through all the institutions of political and social life. And besides that, religion is often the only language people can use in order to enter the public sphere. 
Religious nationalism is a strategy for bounding the collectivity, restoring the nation as a collective agency and it is not a response to poverty, because in religious nationalism, money figures as a symbol of collective power, invested into the nation state that symbolizes importance. That is how God became a universal currency, being in all things, but not identical to any of them, the transcendental signified (Friedland 2002).

Tolerance can be analyzed through public institutions, religious and political institutions, but also through the relationship between people and their experiences. Both lived religion and lived intolerance converge through different aspects of the social, national, secular and sacral context. However, each one of them includes within itself its own opposite, therefore, it is completely impossible to analyze any of them without analyzing intolerance, atheism, and nationalism in essence.

Religious nationalism posits an institutionally specific substance of the social, neither the procedures of self-certain reason nor the play of self-interest, but rather the communal solidarities of faith. Primary practices through which this faith is performed are prayer, religious ritual, pilgrimage, and family life as a site of faith-based solidarity and of divine creation (Friedland 2002). Therefore, family life is organized within the practices of maintaining both power and surveillance through the control of the body. While people live across the institutions, groups may be found outside, on the margins, especially when they struggle within one institution. Also, the first forms of nationalism can be found through different forms of institutional representations, which includes both politics and religion.

Nationalism is a state-centered form of collective subject formation, a form of state representation, one grounding the identity and legitimacy of the state in a population of individuals who inhabit a territory bounded by that state (Friedland 2002). Nationalism is not merely an ideology because it also represents a set of discursive practices by which both territorial and cultural identity can be formed and expressed. Also, it can be seen as a means for the achievement of personal goals, material in its essence.

Money, seen as a fungible bodily fluid, has historically operated as a currency of the public sphere, exchanged from man to man, enabling men to accumulate the reproductive powers of women and to organize the productive forces of other men (Friedland 2002). Therefore, it serves as an erotic fluid whose circuits have been predominantly homosocial, and whose autonomous economy of pleasure contributes to (in Lacaninan words) jouissance of enjoyment, or, surplus of enjoyment. That surplus represents dangerous instrumentality that controls human bodies and reconstructs their identities. In contemporary Bosnia-Herzegovina the national collective body and the individual body exist in parallel spheres; therefore, the self can be imagined only as a unitary, special agent. That is how jouissance of dominance and power has led to intolerance, nationalism and abuses of religion.

\section{5. “The CAIN AND AbEL SYNDROME” AND THE POLITICS OF (IN)TOLERANCE}

According to the early classics, intolerance is generally innocuous, and it exerts little effect on politics because intolerant individuals are politically apathetic, and therefore politically negligible (McClosky and Brill 1983), while political activists and policy making elites tend to be tolerant (Sullivan, et al., 1993). However, these elites are usually under the protection of strong institutions. Contrary to that, more recent studies argue that intolerance is generally pernicious. 
Yet, research confirms both hypotheses. However, even Ignatieff (1999) pointed out that the intolerance between two brothers is even stronger than the intolerance between complete strangers. "The Cain and Abel Syndrome" can be used in order to explain the narcissism of small differences, or, in plain language, reasons why tolerance usually exists only in a virtual way in multiethnic and multireligious societies such as Bosnia-Herzegovina.

The irony whereby those who know most about each other, and differ least from each other, may yet be most intolerant of each other describes conflicts between Bosniaks, Croats and Serbs living in Bosnia-Herzegovina (or, to put it other way round, Muslims, Catholics and the Orthodox). The puzzle of their identities shaped by both ethnicity and religion makes the understanding of their political behavior more complex. Also, the real toleration of their virtual tolerance towards each other complicates the existing situation and leads to the broken society of unrealistic desires.

Those who are closest, geographically, ethnically, religiously, and in other ways, are usually the most divided. However, people at the same time feel very close with strangers, and that, ironically, increases the levels of international solidarity (Mendus 1999). It is not clear whether the establishment of a "group identity" can contribute to the increase of tolerance, or whether multiple collective identities should exist in society. Hence, the more scientists and philosophers talk about tolerance, the more they analyze it as a molecule, the less it exists in the societies. The force to create something that will represent both religious and political tolerance leads societies to the virtual level of common existence.

Robert Orsi (1985) claims that the study of lived religion directs attention to institutions and persons, text and rituals, practice and theology, things and ideas. Both (in)toleration and religion act together while creating one level of meaning and power. That power is something that Foucault was trying to explain through disciplined bodies, More through Utopian society. The complicated puzzle of Bosnian identity exists through the excess of pleasure, excess of the past regimes and the punishment in case of intolerance and nationalism. There is a link between religion, nationalism, sexuality and the body in a way that whenever our nation is invoked we are more likely to refer to patriotism, "love for country", religious values, and punishment for the out-group. Therefore, we might assume that religious nationalism is organized around erotic discourse, gendered order in society, non-disciplined bodies and punishment.

Foucault (1995) claims that what occurs in societies is the production of transgressions and crimes that occurs in a circle in which criminals, policemen and judges are included. In contemporary Bosnia-Herzegovina, the production of tolerance and religious beliefs is in place, and it includes within itself both intolerance and atheism. However, those who do not conform to the group norms that nowadays correspond to the visible religious practice as the important part of the social puzzle can experience consequences on their social and economic status. In that case it is recommended to discipline the non-conformist visible behavior and replace it with the more conformist ideal that fits the jigsaw puzzle of the existing social curriculum that supports the visible production of tolerance, religion, and love towards one's neighbor. Also, if some parts of the puzzle are connected to the different political regimes they have to be dismissed (or at least modified), for the sake of democracy and coexistence.

The engagement in religious practice is not simply governed by group norms. It is more in line with Žižek's analogy of a chocolate laxative - what creates the wound also heals the wound. In the same sense every culture is just a compromise, and engagement in a certain social activity is just a small part of that compromise. People who engage in religious 
practices in contemporary Bosnia-Herzegovina do that in response to a compromise, and in the majority of situations they receive something in return (an intrinsic reward because they truly believe or an extrinsic reward in the shape of social recognition and/or status). In both situations citizens are trained and disciplined to follow the compromise which therefore becomes the rule and regulation. A disciplined body and soul in that case become imprisoned between the old Homo Yugoslavicus, New-Old Man, and New Man who is trying to follow the rules and therefore establish himself in the new society. However, this instrumentalization of knowledge, religion and a complicated past creates the battlefield where those who follow (or at least try to follow) the old rules (Homo Yugoslavicus) and those who embraced (or pretend that they have embraced) the rules of the new society meet and try to interact while balancing between different principles. The dominant religious discourse (or three dominant constituent discourses) create and define different spheres of life in the country: scholarships, employment opportunities, salaries, advancement in career, a voting system, and, above all, a way in which those people enjoy or think of enjoyment.

The psychoanalyst Jacques Lacan (2002) says that we never enjoy something in spite of the law, but because of it. His term jouissance does not describe just an instinctive pleasure or sexual satisfaction, but Freud's Thanatos, or the instinct of death. This is the pleasure principle which works neither as a restriction of pleasure nor as its special part. It includes the possibility to go beyond the pleasure principle resulting in jouissance, organized not in spite of law, but in connection with it. The law does not exist to prevent crime, but to produce it. Also More writes about punishment as an invitation to commit more crimes (More 2003). However, in Bosnia-Herzegovina, the contemporary religious discourse instead of engaging intrinsically religious individuals more actually produces more intolerance due to the excess of both spirituality and imposed beliefs and practices.

Religion is abused as a mean of control, and it continues to exist in a form of omnipresent authority that leads to the excess of nationalism. Regardless of being intrinsically or extrinsically religious, an atheist or someone who just overtly practices religion, group belongingness is a fact that defines one's position in the socio-economic milieu. As religious identities somehow overlap with ethnic identities, (Bosniak - Muslim, Croat - Catholic, Serb - Orthodox), both identifications equally inscribe the identity definition that serves as a certain ticket to certain rights and benefits, such as a job in the government, candidacy for the Presidency, "minority" vs. "majority" status, scholarships etc. Regardless of being an ex comrade who either started to express his/her beliefs publicly, or has never practiced religion but found it good for his current position in society, one has become a part of the larger apparatus that has been producing like-minded three groups of people who have been serving their country since the ratification of the Dayton agreement (or even earlier).

However, Homo Yugoslavicus cannot currently solve the existing puzzle of three constituent people since his/her time has expired and, according to the newly created system, his/her place is in the "Other" group. It is difficult to conclude if these people represent former comrades who rejected being classified as "ex", or whether those people only embraced atheism as their belief and continued living life outside of the religious production of extrinsic values, intolerance and, at the end, nationalism. Studies conducted by psychologists (Petrovic 2010; Puhalo 2015) prove that both atheists and people who lived in the former Yugoslavia and experienced "brotherhood and unity" are more likely to cooperate with other ethnic and religious groups, as well as to forgive and reconcile. However, one cannot claim that being Yugonostalgic and/or being an atheist are preconditions for being open-minded and socially skilled. The point is that we cannot be sure if the fall of communism brought the fall of 
covertly expressed and practiced religious beliefs, or simply, whether the fall of communism brought a new era and New Man who was guided by Darwin's claim that the one who is most responsive to change is the one who survives. However, the newly created system supports the jigsaw puzzle of tripartite identity, while providing only certain benefits to the so-called Other.

The jigsaw puzzle has to be completed successfully, not only on a governmental level, but in all other life areas, including job positions, scholarships, promotions etc. Through overtly expressed religious practices and emphasized religious beliefs a venue for tripartite structure of identity has been created together with a tripartite narrative, discourse and memory as well. Family practices have become institutional practices which, on the contrary, exist in order to discipline groups and preserve social cohesion.

\section{CONCLUSION}

It is still unclear whether Bosnians have been more religious since the aftermath of 1992-1995 war than they used to be before; or if they were simply prevented from expressing their religiosity during the communist regime. However, the short historical overview given in this paper provided certain evidence for the history of group cohesion and (in)tolerance.

Homo Yugoslavicus continues to exist through the family practices and those who still embrace the idea of brotherhood and unity. However, the current discourse and the existence of several parts of the puzzle that forms the Bosnian identity contribute more to the production of intolerance and nationalist rhetoric rather than to group cohesion and reconciliation between different ethnic/religious groups. We could conclude that the overlap between ethnic and religious identity contributes to the formation of the jigsaw puzzle of complicated identity structure of contemporary Bosniak, Serb and/or Croat (Muslim, Orthodox and Catholic, respectively).

However, between these three narratives one can also find hundreds (or even more) parallel discourses that exist in the same time and space. The major differences between them are not even visible, but they can be easily discovered through the analysis of disciplined bodies that exist within each system. Also, nationalism that leads to intolerance through the usage of several means (religion, politics, money, sex), can also be understood through the analysis of thanatopolitics created with the purpose of controlling newly established narratives and types of enjoyment.

Toleration always involves power relations, where those "in power" decide how to tolerate the "intolerable". The current situation in Bosnia-Herzegovina reveals that both religion and tolerance are in the realm of those who possess power. People engage in religious practices in order to fulfill a certain need, either spiritual or material. However, the type of reward one is seeking is what differentiates between one who believes intrinsically and one who wants to achieve something material: promotion, status, or at least - recognition for behaving in a socially accepted way. Therefore, discourse of religion and tolerance is formed according to the identity puzzle (based on what type of small pieces of puzzle form the identity of those in power). The presence of those who either live in a different system (yugonostalgic people, Homo Yugoslavicus), or those who do not believe (atheists) simply adds a new dimension to the currently established system which can be used to further explain if the overtly expressed beliefs will remain unchanged in case of the establishment of a new system. 


\section{REFERENCES}

Bjelić, Dušan I. "The Balkans: Europe's Cesspool.” Cultural Critique 62 (2006): 33-66. Accessed September 25, 2014. url: http://www.jstor.org/stable/4489235.

Bringa, Tone. "Islam and the Quest for Identity in Post-Communist Bosnia-Herzegovina." In Islam and Bosnia: Conflict Resolution and Foreign Policy in Multi-Ethnic States, edited by Maya Shatzmiller, 24-35. Montreal: McGill-Queen's University Press, 2002.

Cladis, Mark S., and Carol Cosman, trans. The Elementary Form of Religious Life by Emil Durkheim. New York: Oxford University Press, 2008.

Cohen, Lenard."Bosnia's 'Tribal Gods': The Role of Religion in Nationalist Politics." In Religion and the War in Bosnia, edited by Paul Mojzes, 43-73. Atlanta: American Academy of Religion Scholars Press, 1998.

Derrida, Jacques. "Faith and Knowledge: The Two Sources of 'Religion' at the Limits of Reason Alone." In Religion: Cultural Memory in the Present, edited by Jacques Derrida and Gianni Vattimo, 1-78. Stanford, Cambridge: Polity, 1998.

Đorđević, Dragoljub B. "Religious-ethnic Panorama of the Balkans." The Balkans in Transition, edited by Nevill S. Arrachichige Don and Ljubisa Mitrovic, 79-93. San Francisco: International Research Foundation for Development / Niš: Center for Balkan Studies, 2007.

Foucault, Michel. Discipline and Punish: The Birth of the Prison. $2^{\text {nd }}$ Ed. Translated by A. Sheridan. UK: Vintage Books, 1995.

Freud, Sigmund. The Standard Edition of the Complete Psychological Works. Translated by J. Strachey, A. Freud, A. Strachey and A. Tyson. London: Hogarth Press, 1968.

Friedland, Roger. "Money, Sex, and God: The Erotic Logic of Religious Nationalism." Sociological Theory 20, 3 (2002): 381-425. Accessed September 20, 2014. url: http://www.jstor.org/stable/3108617.

Froese, Paul. „After Atheism: An Analysis of Religious Monopolies in the Post-Communist World.“ Sociology of Religion 65 (2004a): 57-75.

Froese, Paul. "Forced Secularization in Soviet Russia: Why an Atheistic Monopoly Failed." Journal for the Scientific Study of Religion 43, 1 (2004b): 35-50.

Gallop, Jane. "Impertinent Question: Irigaray, Sade, Lacan.” SubStance 9, 1 (1980): 57-67. Accessed September 20, 2014. URL: www.jstor.org/stable/3683929.

Hacic-Vlahovic, Ana. "(De)Secularization in Bosnia-Herzegovina An Examination of Religiosity Trends in a Multi-Ethnic Society." Amsterdam Social Science 1, 1 (2008): 72-86.

Ignatieff, Michael. (1999) "Nationalism and Toleration." In Politics of Toleration. Tolerance and Intolerance in Modern Life, edited by Susan Mendus, 77-106. Edinburgh: University of Edinburgh Press.

Kristeva, Julia. Powers of Horror: An Essay on Abjection. Translated by L.S. Roudiez. New York: Columbia University Press, 1982

Kristeva, Julia. In the Beginning Was Love: Psychoanalysis and Faith. Translated by A. Goldhammer. New York: Columbia University Press, 1988.

Kristeva, Julia. Crisis of the European Subject. Translated by S. Fairfield. New York: Other Press, 2000.

Lacan, Jacques. Écrits. A Selection. Translated by B. Fink. New York: W.W.Norton, 2002.

McClosky, Herbert, and Alida, Brill. Dimensions of Tolerance: What Americans Believe about Civil Liberties. New York: Russell Sage, 1983

Mendus, Susan. Politics of Toleration. Tolerance and Intolerance in Modern Life. Edinburgh: Edinburgh University Press, 1999.

More, Tomaso. Utopia. London: Penguin Books, 2003.

Orsi, A. Robert. The Madonna of $115^{\text {th }}$ Street: Faith and Community in Italian Harlem 1880-1950. New Heaven: Yale University Press, 1985.

Petrović, Nebojša. "Sociopsihološki aspekti pomirenja u BiH. Nakon 15 godina mira." In Spremnost na pomirenje u BiH, edited by Srđan Puhalo, Nebojša Petrović, and Neda Perišić, 13-60. Sarajevo: Frierich Ebert Stiftung, 2010

Puhalo, Srđan. "Koliko su vijernici u Bosni i Hercegovini spremni na pomirenje." In Book of Proceedings of the First International Symposium on Culture of Remembrance in Bosnia-Herzegovina, edited by Sabahudin Hadžialić and Alma Jeftić, 211-231. Sarajevo: Diogen pro Culture Magasine, 2015.

Rogobete, Silviu.E. "The Interplay of Ethnic and Religious Identities in Europe: A Possible Mapping of a Complex Territory." Europolis 6 (2009): 563-584.

Sullivan, John. L., Walsh, Pat., Shamir, Michal, Barnum, David. G., Gibson, James. L. "Why Politicians are More Tolerant: Selective Recruitment and Socialization among Political Elites in Britain, Israel, New Zealand, and the United States." British Journal of Political Science 23, 1 (1993): 51-76. Accessed September 18, 2014. url: http://www.jstor.org/stable/194067. 
Van Den Berg, Mariecke., Bos, David. J., Derks, Marco, Ganzevoort, Ruard., Jovanović, Miloš., Korte, AnneMarie., Sremac, Srđan. "Religion, Homosexuality, and Contested Social Orders in the Netherlands, the Western Balkans, and the Sweden." In Religion in Times of Crisis, edited by Gladys Ganiel, Heidemarie Winkel, and Christopher Monnot, 116-134. Leiden/Boston: Brill, 2014.

Velikonja, Mitja. Religious Separation and Political Intolerance in Bosnia-Herzegovina. Bryan, TX: Texas A\&M University Press, 2003.

\section{BOSANSKI IDENTITET IZMEĐU NACIONALIZMA, (NE)TOLERANCIJE I (A)TEIZMA}

U ovom radu analiziraju se istorijske promene u praktikovanju religije u Bosni i Hercegovini od komunizma do posleratnog perioda u skladu sa njihovim utecajem na identitet i međugrupne (međuentitetske, međureligijske) odnose. Ne postoji dovoljno dokaza o skrivenom praktikovanju religije tokom komunizma, kao ni o početku javnog uključivanja u religijsku praksu tokom i nakon rata 1992-1995 s ciljem uspostavljanja bolje unutragrupne povezanosti, kohzije $i$ zadovoljenja određenih potreba. "Bosanski identitet" je zamišljen kao puzla formirana od "ostataka" prethodnog režima i "novih dodataka" iz posleratnog perioda. Diskurs moċi dominira u Bosni i Hercegovini $i$ onemogućava različite vidove dijaloga koji mogu dovesti do boljeg razumevanja različitosti i Drugog. Osnovni problem koji se razmatra u ovom radu je (ne)postojeci bosanski identitet analiziran kroz "jouissance" nacionalizma, netolerancije i religije. Kontradikcija sa Frojdovim konceptom identifikacije $i$ odnos tog koncepta prema telu $i$ moci $u$ posleratnom podeljenom društvu ce biti posebno razmotrena. Zaključak je da glavni diskurs moci deluje zajedno sa religijom kako bi se oformirala "puzla bosanskog identiteta". Prisustvo onih koji još uvek žive u drugačijem sistemu (jugonostalgičari, Homo Yugoslavicus) ili onih koji ne veruju (ateisti) dodaje novu dimenziju već formiranom sistemu koja se može koristiti kako bi se analiziralo da li bi trenutno javno izražena uverenja ostala nepromenjena u slučaju uspostavljanja novog sistema.

Ključne reči: identitet, netolerancija, religija, komunizam, Homo Yugoslavicus, Bosna i Hercegovina 